\title{
FORMULATION AND IN VITRO EVALUATION OF GASTRORETENTIVE FLOATING BEADS OF AMOXICILLIN USING PECTIN FROM BANANA PEEL (MUSA BALBISIANA ABB)
}

\author{
YAN HENDRIKA*, JULIA REVENY, SUMAIYAH SUMAIYAH \\ Departement of Pharmaceutical Technology, Faculty of Pharmacy, Universitas Sumatera Utara, Medan, Indonesia. \\ Email: yan.hendrika20@gmail.com
}

Received: 07 November 2017, Revised and Accepted: 15 December 2017

\section{ABSTRACT}

Objective: The study aimed to investigate the characteristic pectin from banana peels (Musa balbisiana ABB) and formulation as a polymeric carrier in gastrorententive floating beads.

Methods: Pectin from banana peel was isolated using a citric acid solvent with varying concentration $(2.5 \%, 5 \%$, and $7.5 \%)$ at $80^{\circ} \mathrm{C}$ for 90 min. Characterization of pectin included determination of yield, equivalent weight methoxyl content (Me), galacturonic acid (GaA), and degree esterification. Floating beads of amoxicillin prepared by the ionotropic gelation method used calcium ion as cross-linking and sodium bicarbonate as gas-forming agent. Three formulations of amoxicillin were formulated using different percentage of pectin. The prepared beads were evaluated for particle size, drug entrapment efficiency, morphological study, floating lag time, floating time, swelling properties, in vitro drug release, and study of drug release kinetics.

Results: The result showed citric acid concentration $7.5 \%$ was optimum condition for isolated pectin from banana peels with the percent of yield was 9.51\%; 6.29\% Me; 62.82\% GaA; and degree of esterification $48.46 \%$. Floating time of beads was $\geq 12 \mathrm{~h}$ and drug entrapment efficiency F3 was highest (51\%). In vitro drug release confirmed F3 was the best formulation as it releases $92 \%$ at $5 \mathrm{~h}$ with followed Higuchi model kinetics drug release. Floating beads amoxicillin showed differences of drug release compared with conventional dosage form of amoxicillin ( $\mathrm{p}<0.05$ ).

Conclusion: This study confirmed these beads can entrap amoxicillin and also can successfully deliver the drug targeted stomach for a prolong duration drug release.

Keywords: Pectin, Banana peel, Musa balbisiana ABB, Gastroretentive, Floating beads, Amoxicillin.

(C) 2018 The Authors. Published by Innovare Academic Sciences Pvt Ltd. This is an open access article under the CC BY license (http://creativecommons. org/licenses/by/4. 0/) DOI: http://dx.doi.org/10.22159/ajpcr.2018.v11i4.23511

\section{INTRODUCTION}

Amoxicillin is mainly antibiotic for gastric ulcer diseases against Helicobacter pylori combining with metronidazol or clarithromycin and proton pump inhibitor [1]. However, therapy of gastric ulcer patients with amoxicillin conventional oral dosage form is ineffective even at high daily doses, apparently due to limited contact time with the target site [2] and H. pylori lives mainly in the surface mucus layer [3].

Gastroretentive (floating, high density, swelling, bioadhesive, etc.) is a strategy has been developed to prolong the gastric residence time of dosage forms and targeting the gastric mucosa, especially for gastric ulcer therapy [4,5]. Floating drug delivery systems (FDDS) are one of many important approaches to achieve gastric retention to obtain sufficient drug bioavailability and desirable for drugs with an absorption window in the stomach or in the upper small intestine. Non-effervescent FDDS and effervescent FDDS have been utilized in the development of FDDS [6].

Pectin (Fig. 1) is a complex family of heteropolysaccharides that constitute a large proportion of the primary cell wall plants that use to applications in the pharmaceutical and biotechnology industry $[7,8]$. Pectin is divided into two main categories on the basis of its different gelling properties: High methoxyl pectin (HM pectin), which is characterized by a degree of esterification (DE) above $50 \%$, and low methoxyl pectin (LMP) has a DE below 50\%. HM pectin forms gels with sugar and acid and LMP requires the presence of calcium ions (or other multivalent cations) for proper gel formation, "egg box" [9].

The use of pectin of developing an oral controlled release drug delivery system has been reported: Matrix tablets, gel beads, gel coating, beads, microparticles, film, nanoparticles, mucoadhesive $[9,10]$, and microspheres gastroretentive [11].

Pectin is a family of complex polysaccharides present in the junctional zone between cells within secondary cell walls including xylem and fiber cells in woody tissue that surround growing and dividing plant cells [12]. Characteristic of pectin is related to many factors including the type of fruit, extraction method, process purification, and drying [13]. General method for pectin extraction by solvent-liquid methods in acidic aqueous media ( $\mathrm{HCl}$, acid citric, and acetic acid) at high temperatures [14].

Indonesia is one of the largest banana producers with totals of banana peel waste up to $40 \%$. In general, banana peels have just used as feeding cattle [15]. Biological activity of banana peels had reported that antioxidant, antimicrobial activity, etc. Banana peels are also a good source of pectin (9-22\%) [16].

Therefore, the aim of the present study was to characterize pectin from banana peels and characterization floating beads amoxicillin used pectin from banana peels.

\section{METHODS}

\section{Materials}

Banana peels, Amoxicillin (Sigma-Aldrich), citric acid (Merck), sodium hydroxide (Merck), indicator phenolphthalein (Merck), calcium chloride (Merck), hydrochloric chloride (Merck), sodium bicarbonate (Merck), and acetic acid (Bratachem). 


\section{Methods}

Pectin extraction

Fresh peels of banana Musa balbisiana ABB were washed and oven dried at $50^{\circ} \mathrm{C}$ temperature for 1 week. The dried plant material was made into a coarse powder and stocked at a later use.

About $100 \mathrm{~g}$ dried powder of banana peels was separately treated with $1000 \mathrm{ml}$ citric acid solvent (concentration $2.5 \%, 5 \%$, and $7.5 \%$ ) at $80^{\circ} \mathrm{C}$. The mixture was stirred continuously for $90 \mathrm{~min}$. The resulting extract was filtered through nylon cloth and allowed to cool at room temperature. Ethanol $96 \%$ was added in ratio $1: 2(\mathrm{v} / \mathrm{v})$ to precipitate pectin, precipitated was filtered through nylon cloth. The extracted pectin was washed 3 times with ethanol $96 \%$, and drying at $50^{\circ} \mathrm{C}$ for $12 \mathrm{~h}$. Collected pectin was ground and sieved (mesh no. 60) for characterization and formulation. Pectin was characterized includes determination of yield, equivalent weight (EW), methoxyl content, gaacturonic acid (GaA), and DE following a method described by Nazaruddin et al., 2013 [17].

\section{Characterization of pectin}

Determination of yield

The pectin yield was calculated using equation (a):

Swelling indexs $=\frac{\mathrm{Wt}-\mathrm{W} 0}{\mathrm{~W} 0} \times 100 \%$

Where, $\mathrm{p}=$ collected pectin (gram), $\mathrm{rm}=$ weight of raw material (gram).

\section{Determination of EW}

It was determined by titration with $0.1 \mathrm{~N} \mathrm{NaOH}$ (Titration I) using phenolphthalein indicator. EW was calculated using the equation:

$$
\mathrm{EW}=\frac{\text { Weight of }(\mathrm{g})}{\text { mlof } \mathrm{NAoH} \times \mathrm{NNAoH}} \times 1000
$$

\section{Determination of methoxyl content (Me)}

To the neutral solution of titration I added $25 \mathrm{ml}$ of $0.25 \mathrm{~N} \mathrm{NaOH}$ shaked and was allowed to stand for $30 \mathrm{~min}$ at room temperature. To the solution was added $25 \mathrm{ml}$ of $0.25 \mathrm{~N} \mathrm{HCl}$, phenolphthalein indicator and was titrated with $0.1 \mathrm{~N} \mathrm{NaOH}$ (Titration II). Me was calculated using the equation:

$$
\mathrm{ME}=\frac{\text { mlof } \mathrm{NAoH} \times \mathrm{NNAoH} \times 3.1}{\text { Weight of pencin }(\mathrm{g})} \times 1000
$$

\section{Determination of GaA}

GaA was calculated using data $\mathrm{ml}$ of $\mathrm{NaOH}$ from titrated I and II

$$
\begin{aligned}
& \operatorname{GaA}(\%)=\frac{176 \times 100}{\mathrm{z}} \\
& \mathrm{z}=\frac{\text { Weight of pectin }(\mathrm{mg})}{\text { meqTitration } \mathrm{I}+\text { meqTitration II }}
\end{aligned}
$$

where, 176 is molecular weight of AUA.

\section{Determination of $D E$}

The degree of DE esterification was calculated according to equation: [17]

$\operatorname{DE}(\%)=\frac{176 \times \mathrm{Me} \times 100}{31 \times \mathrm{AUA} \%}$

\section{Preparation of amoxicillin floating beads}

Amoxicillin floating beads were prepared by an ionotropic gelation method using different concentrations of pectin. Pectin was dissolved three different concentrations $(1.25 \%, 1.5 \%$, and $1.75 \% \mathrm{w} / \mathrm{v})$ in $10 \mathrm{ml}$ distilled water with stirring. $\mathrm{NaHCO}_{3}$ as gas forming and $500 \mathrm{mg}$ amoxicillin was added to pectin solution and stirring continuously for $15 \mathrm{~min}$ to resulting uniform solution. The resulting solution was dropped extruded through a $23 \mathrm{G}$ syringe needle from a distance $5 \mathrm{~cm}$ into $20 \mathrm{ml}$ calcium chloride solution $(2 \% \mathrm{w} / \mathrm{v})$ containing $10 \%(\mathrm{v} / \mathrm{v})$ acetic acid. The solution containing beads was stirred $50 \mathrm{rpm}$ using a magnetic bar to improve the mechanical strength of the beads and allowed to complete the gas reaction. The resulting beads were filtered and washed with distilled water and dried using freeze dryer [18]. The formulations are shown in Table 1.

\section{Evaluation of floating beads}

Study of particle size, weight, and surface morphology

The diameter of beads was determined by screw gauge. 10 dried beads were randomly selected from each batch, then calculating the mean diameter of beads. All the formulated batches of pectin buoyant beads were visually analyzed for shape and color [18].

Morphological examination of floating beads surface using a scanning electronic microscope (Hitachi, TM3000)

\section{Determination of drug entrapment}

The amount of drug entrapment was estimated by free drug infiltrate solution resulting from preparation beads, transferred to a $50 \mathrm{ml}$ volumetric flask and the volume was made up using $0.1 \mathrm{~N} \mathrm{HCl}$. The solution was assayed by spectrophotometrically at $228 \mathrm{~nm}$ using an ultraviolet (UV) spectrophotometer (UV-1800, Shimadzu). The amount of drug entrapped in beads was calculated by the following equation:

$$
\begin{gathered}
\text { Theoreticaldrugloaded }(\mathrm{g}) \\
\text { Drugentrapment }=\frac{- \text { freedrug }(\mathrm{g})}{\text { Theoreticaldrugloaded }(\mathrm{g})} \times 100 \%
\end{gathered}
$$

\section{Floating lag time and floating time}

A total of 10 beads were placed in a beaker glass filled with $100 \mathrm{ml}$ of $\mathrm{HCl}$ solution, temperature was maintained at $37^{\circ} \mathrm{C}$. The floating lag time count to beads floating complete. The floating time of beads observed for $12 \mathrm{~h}[19]$.

\section{Swelling studies}

The swelling properties of floating beads were determined in simulated gastric fluid ( $\mathrm{pH}$ 1.2). Sample dried floating beads of known weight $(50 \mathrm{mg}$ ) were placed in a beaker containing $100 \mathrm{ml}$ of simulated gastric fluid maintained at $37^{\circ} \mathrm{C}$. The swollen beads were periodically removed, filtered, and weighed. The experiments were done in triplicate. The percentage of swelling ratio of the beads was calculated from the formula [18].

Swelling indexs $=\frac{\mathrm{Wt}-\mathrm{W} 0}{\mathrm{~W} 0} \times 100 \%$

Where, $\mathrm{Wt}=$ Final weight of beads $\mathrm{W} 0=$ Initial weight of beads.

\section{In vitro drug release studies}

The in vitro of the drug from beads were carried out for $300 \mathrm{~min}$ using USP Type II dissolution apparatus containing $900 \mathrm{ml}$ of simulated gastric fluid $\left(0,1 \mathrm{~N} \mathrm{HCl} \mathrm{pH} \mathrm{1.2)} \mathrm{maintained} \mathrm{at} 37 \pm 0.5^{\circ} \mathrm{C}\right.$ and speed of agitation at $50 \mathrm{rpm}$. At fixed times intervals, aliquots $(5 \mathrm{ml})$ were collected and replaced with a fresh dissolution medium. The collected samples were analyzed at $\lambda_{\text {max }} 228 \mathrm{~nm}$ using UV spectrophotometer (UV-1800, Shimadzu). The studies were carried out in triplicate. The percent of drug released at various time intervals was calculated and plotted against time [18]. 
Table 1: Formulation of floating beads amoxicillin

\begin{tabular}{llll}
\hline Batch code & Amoxicillin (in mg) & Pectin concentration (\%) & CaCl $_{\mathbf{2}}(\mathbf{\%})$ \\
\hline F1 & 500 & 1,25 & 50 \\
F2 & 500 & 1,5 & 50 \\
F3 & 500 & 1,75 & 2 \\
\hline
\end{tabular}

Kinetics drug release studies

Study of the drug release kinetics of amoxicillin from beads was subjected to zero order, first order, the Higuchi model [20], and Korsmeyer-Peppas model for analyzing the mechanism release of drug.

Zero order $\left(\mathrm{Q} t=\mathrm{Q}_{0}+\mathrm{K}_{0} \mathrm{t}\right)$, first order (ln $\mathrm{Q}_{\mathrm{t}}=\ln \mathrm{Q}_{0}+\mathrm{K} 1_{\mathrm{t}}$ ), and Higuchi $(\mathrm{Qt}=\mathrm{Kt} 1 / 2)$ model were fitted to dissolution data of optimized batch, i.e., H-1, using linear regression analysis. Zero-order kinetic describes the system where the release rate of drug is independent of its concentration; first-order kinetics indicates time-dependent release kinetics. Higuchi published the probably most famous and most often used mathematical equation to describe the drug release from matrix system. This model is often applicable to the different geometries and porous system [21,22].

\section{Mechanism of drug release}

To analyze the mechanism of drug release, first $60 \%$ of drug release data was fitted in Korsmeyer-Peppas model. Korsmeyer is a simple relationship which described the drug release from a polymeric system equation. For matrix, if the exponent $n=0.45$, then, the drug release mechanism is Fickian diffusion, and if $0.45<\mathrm{n}<0.89$, then, it is non-Fickian or anomalous diffusion. An exponent value of 0.89 is indicative of Case-II Transport or typical zero-order release [23]. To study the release kinetics, data obtained from in vitro drug release studies were plotted as log cumulative percentage drug release versus log time [24].

\section{RESULT}

\section{Characteristics of pectin}

EW, Me, AUA, and DE content was quantitatively determined by the titration method. Pectin characteristics are shown in Table 2.

\section{Evaluation of beads}

Color, particle size, weight, and surface morphology

The prepared beads, particle size and weight determination, were shown in Table 3 and Fig. 3.

Morphological characterization of floating beads of amoxicillin was done by taking scanning electronic microscopy (Hitachi, TM3000). Beads were found to be well-rounded spheres, surging with pores to the drug release. The SEM pictures are beads shown in Fig. 4.

\section{Drug entrapment efficiency}

Determination of drug entrapment to all formulas is shown in Fig. 5.

Floating lag time and floating time

The floating lag time of floating beads ranged from 18 to $30 \mathrm{~s}$ and floating time to all formulas are $>12 \mathrm{~h}$. Floating lag time and floating time shown in Table 3.

\section{Swelling properties}

The mean swelling to dried beads in simulated gastric fluid $(0.1 \mathrm{~N} \mathrm{HCl}$, $\mathrm{pH} 1.2$ ) was found up to $30 \%$. The swelling properties of floating beads are shown in Fig. 6.

\section{In vitro drug release and kinetics drug release}

Both the formulation of floating beads was evaluated in simulated gastric fluid $(0.1 \mathrm{~N} \mathrm{HCl}, \mathrm{pH} 1.2)$ for $8 \mathrm{~h}$. The percentage release of amoxicillin from all formulation floating beads and conventional dosage form is shown in Table 4.
Table 2: Characteristic of pectin

\begin{tabular}{lllll}
\hline Pectin (\%) & EW & Me (\%) & GaA (\%) & DE (\%) \\
\hline CA 2.5 & 585.6 & 5.77 & 62.82 & 52.16 \\
CA 5 & 544.5 & 5.96 & 66.16 & 51.14 \\
CA 7.5 & 463.23 & 6.29 & 73.72 & 48.46 \\
\hline
\end{tabular}

CA: Citric acid. EW: Equivalent weight, GaA: Galacturonic acid, DE: Degree of esterification, Me: Methoxyl content

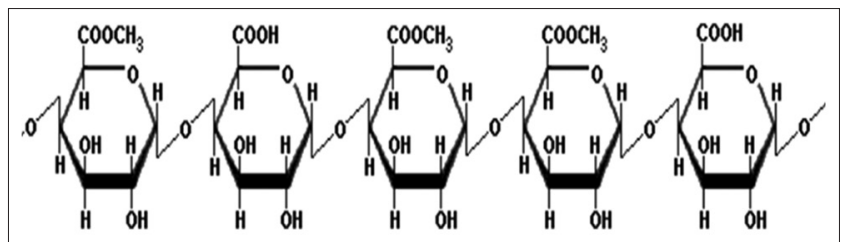

Fig. 1: Pectin structure

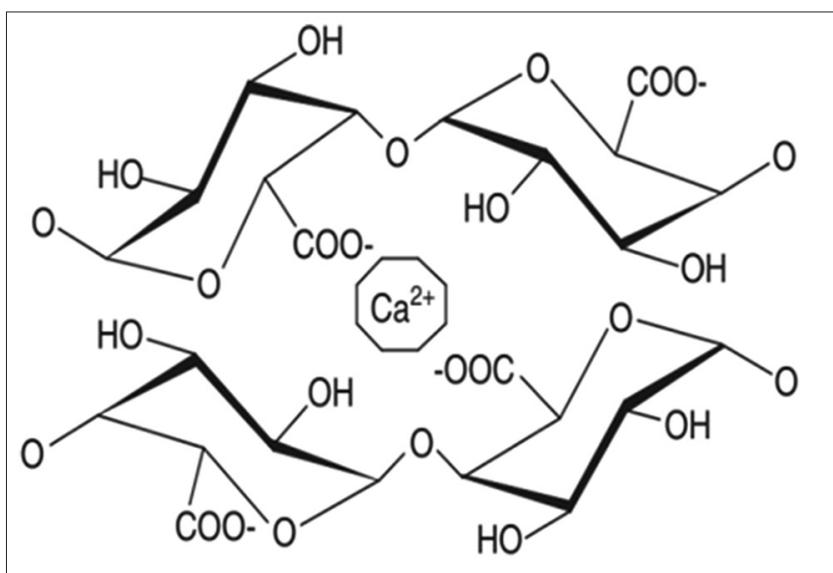

Fig. 2: Pectin-ion calcium interaction "egg box conformation"

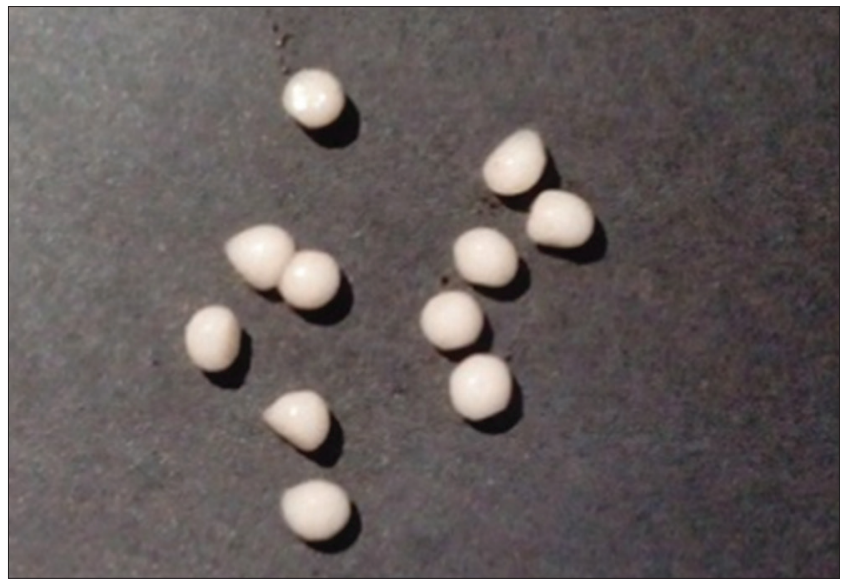

Fig. 3: Organoleptic of floating beads

The drug release kinetics is presented in Table 5 and follows a complex order drug release. To know the mechanism of drug release, data were treated according to four models: Zero-order release, first-order release, Higuchi models, and Korsmeyer-Peppas equation. 


\section{DISCUSSION}

\section{Characteristics of pectin}

Yield of pectin using three variations of citric acid 2.5\% (pH 2.7), 5\% (pH 2.2), and 7.5\% (pH 1.8) obtained was in each 3.8\%, 8.5\%, and $9.51 \%(\mathrm{w} / \mathrm{w})$. The result indicated that yield of pectin was strongly $\mathrm{pH}$ dependent that the yield tended to increase with an increase in the strength of (acid) acidic media. Organoleptic properties of pectin were found powder with brownish-white color.

The EW of pectins ranged from 463.23 to 585.6. Increase free acid resulted EW decrease. It showed higher degradation of isolated pectin polymer is $\mathrm{pH}$ dependent.

The Me of pectin ranged from 5.96 to $6.29 \%$, indicating that pectins polymers from banana peels are LMP group. Acid citric $7.55 \%$ showed the optimum concentration to pectin extraction from banana peels. The Me has related with gel properties of pectin.

The GaA content of pectin from banana peels ranged from 62.82 to $73.72 \%$. The highest amount of GaA was obtained at the lowest pH 1.8 . At $\mathrm{pH} 1.8$ was higher degradation of isolated pectin of isolated pectin polymers into shorter oligomers.
The DE of pectin from banana peels extracted by citric acid ranged from 48.46 to $52.16 \%$, indicating that pectins from banana peels extracted, including to LMP or low degree ester pectin. The Me of pectin related to gel properties of pectin. LMP can be gel in the presence of divalent cations, usually calcium.

\section{Evaluation of beads}

The means bead size was found from 0.21 to $0.23 \mathrm{~mm}$, and means the weight of beads ranged from 9.82 to $11.24 \mathrm{mg}$, indicated there are relation concentration polymer and particle size and weight of beads. To generate uniformity in size and weight of beads that synthesis conditions such as stirring rate, a distance of the drop, and rate of falling of the drop must be same.

Morphological characterization of floating beads of amoxicillin was found to be well-rounded spheres, surging with pores to the drug release.

Drug entrapment efficiency to all formula form $45 \%$ up to $50 \%$, and the drug entrapment efficiency depends on the concentration of polymer used. A correlation was also seen to exist between the concentration of polymers, particle size and weight, and drug entrapment. The floating beads of batch F3 formulation (pectin 1.75\%) showed the higher entrapment efficiency up to $57 \%$

Table 3: Characteristic of floating beads

\begin{tabular}{|c|c|c|c|c|c|c|}
\hline \multirow[t]{2}{*}{ Batch } & \multirow[t]{2}{*}{ Shape } & \multirow[t]{2}{*}{ Color of beads } & \multicolumn{2}{|l|}{ Mean \pm SD } & \multirow[t]{2}{*}{ Floating lag time (sec) } & \multirow[t]{2}{*}{ Floating time (h) } \\
\hline & & & Mean diameter & Mean weight & & \\
\hline F1 & Spherical & Brownish & $9.82 \pm 0.4207$ & $0.21 \pm 0.0071$ & 30 & $>12$ \\
\hline F2 & Spherical & Brownish & $10.16 \pm 0.2702$ & $0.224 \pm 0.0055$ & 18 & $>12$ \\
\hline F3 & $\begin{array}{l}\text { Spherical with } \\
\text { tailing }\end{array}$ & Brownish & $11.24 \pm 0.1342$ & $0.236 \pm 0.0055$ & 20 & $>12$ \\
\hline
\end{tabular}

SD: Standard deviation

Table 4: Cumulative drug release

\begin{tabular}{|c|c|c|c|c|}
\hline \multirow[t]{2}{*}{ Time (min) } & \multicolumn{4}{|c|}{ Drug release $(\%) \pm S D$} \\
\hline & F1 & F2 & F3 & Conventional \\
\hline 5 & $4.79 \pm 0.391^{*}$ & $5.89 \pm 0.951^{*}$ & $5.65 \pm 0.445^{*}$ & $51.7 \pm 1.351$ \\
\hline 10 & $8.32 \pm 0.45^{*}$ & $12.81 \pm 0.281^{*}$ & $9.52 \pm 0.133^{*}$ & $57.4 \pm 1.047$ \\
\hline 15 & $12.60 \pm 0.795^{*}$ & $18.51 \pm 0.266^{*}$ & $13.69 \pm 0.190 *$ & $70.1 \pm 1.963$ \\
\hline 20 & $19.52 \pm 0.726^{*}$ & $23.83 \pm 0.383^{*}$ & $18.17 \pm 0.291^{*}$ & $86.75 \pm 1.09$ \\
\hline 30 & $26.56 \pm 0.907 *$ & $28.42 \pm 0.282^{*}$ & $23.67 \pm 0.173^{*}$ & $97.50 \pm 0.482$ \\
\hline 45 & $32.27 \pm 0.832^{*}$ & $35.73 \pm 1.647^{*}$ & $27.62 \pm 0.187 *$ & $98.58 \pm 0.655$ \\
\hline 60 & $39.99 \pm 1.148 *$ & $41.17 \pm 0.492^{*}$ & $34.38 \pm 0.302 *$ & $99.16 \pm 0.486$ \\
\hline 90 & $47.97 \pm 0.806^{*}$ & $48.23 \pm 1.354^{*}$ & $42.01 \pm 1.001^{*}$ & $99.33 \pm 0.694$ \\
\hline 120 & $53.66 \pm 0.429 *$ & $55.88 \pm 0.314^{*}$ & $53.26 \pm 0.803^{*}$ & $100.14 \pm 0.643$ \\
\hline 150 & $64.16 \pm 0.352^{*}$ & $67.51 \pm 0.232 *$ & $61.94 \pm 0.880^{*}$ & $100.14 \pm 0.643$ \\
\hline 180 & $74.27 \pm 0.83^{*}$ & $75.59 \pm 1.559^{*}$ & $74.42 \pm 1.699^{*}$ & $100.14 \pm 0.643$ \\
\hline 240 & $83.13 \pm 1.401^{*}$ & $87.53 \pm 1.631^{*}$ & $83.61 \pm 1.183^{*}$ & $100.14 \pm 0.643$ \\
\hline 300 & $96.45 \pm 2.670^{*}$ & $96.59 \pm 0.928^{*}$ & $92.88 \pm 1.997 *$ & $100.14 \pm 0.643$ \\
\hline 360 & $96.85 \pm 1.126^{*}$ & $98.70 \pm 1.205^{*}$ & $96.10 \pm 1.260^{*}$ & $100.14 \pm 0.643$ \\
\hline 420 & $96.94 \pm 1.407^{*}$ & $98.12 \pm 1.584 *$ & $99.23 \pm 0.741^{*}$ & $100.14 \pm 0.643$ \\
\hline 480 & $98.7 \pm 4.192^{*}$ & $98.15 \pm 1.858^{*}$ & $97.72 \pm 1.437^{*}$ & $100.14 \pm 0.643$ \\
\hline
\end{tabular}

*Means significantly differences compared with conventional dosage form ( $\mathrm{p}<0.05)$. SD: Standard deviation

Table 5: Kinetic models drug release

\begin{tabular}{llllll}
\hline Batch & \multicolumn{2}{l}{ Models of drug release } & & \\
\cline { 2 - 6 } & Zero order $\left(\mathbf{R}^{2}\right)$ & First order $\left(\mathbf{R}^{2}\right)$ & Higuchi model $\left(\mathbf{R}^{2}\right)$ & \multicolumn{2}{l}{ Korsmeyer-Peppas model } \\
\cline { 3 - 6 } & & & & 0.977 & 0.781 \\
& & 0.693 & 0.996 & 0.973 & 0.665 \\
\hline F1 & 0.951 & 0.702 & 0.996 & 0.994 & 0.691 \\
F2 & 0.952 & 0.760 & 0.993 & & \\
\hline
\end{tabular}




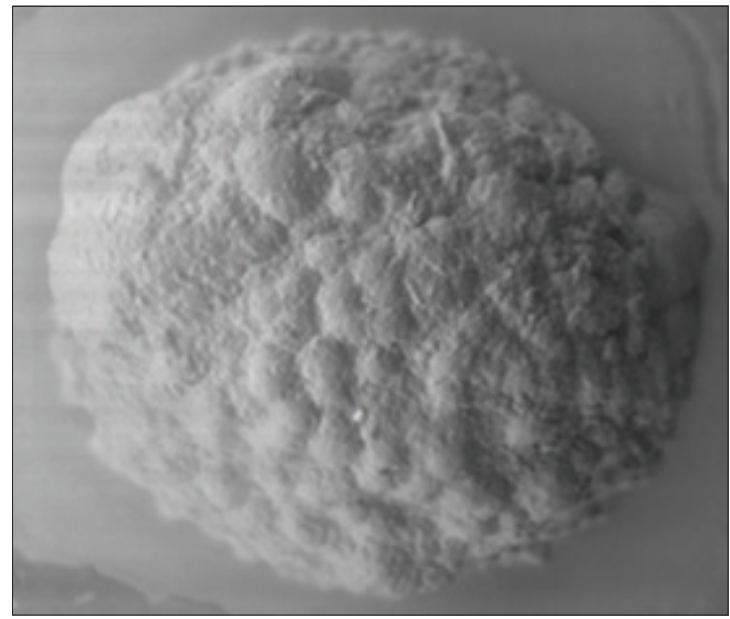

Fig. 4: SEM micrograph of floating beads

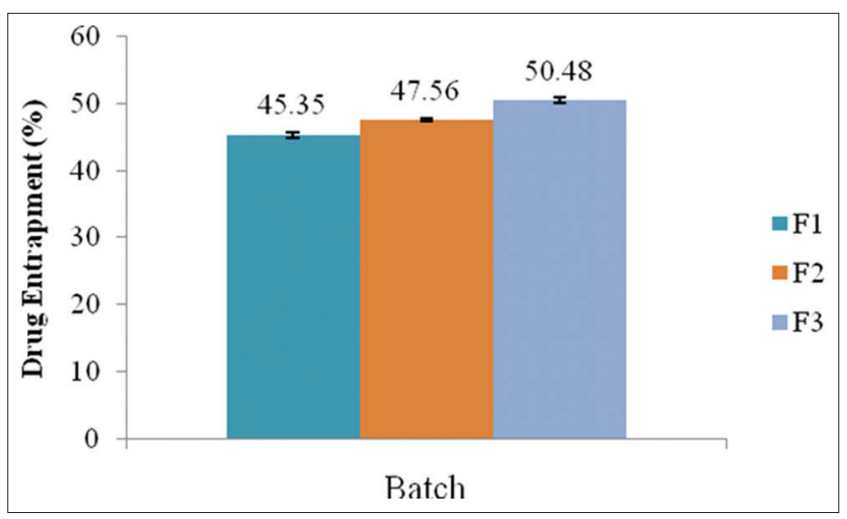

Fig. 5: Drug entrapment efficiency

The floating lag time of floating beads ranged from 18 to $30 \mathrm{~s}$ and floating time to all formulas are $>12 \mathrm{~h}$.

The mean swelling to dried beads in simulated gastric fluid $(0.1 \mathrm{~N}$ $\mathrm{HCl}, \mathrm{pH} 1.2$ ) was found up to $30 \%$. The swelling properties indicated floating beads pectin may begin to swell more and behave as matrices for controlled release of incorporated drug.

\section{In vitro drug release and kinetics drug release}

The results indicated that drug release of floating beads amoxicillin (F1, F2, and F3) was found that approximately $90 \%$ drug release after $300 \mathrm{~min}$. The results indicated that drug release of floating beads amoxicillin (F1, F2, and F3) does not meet the criteria requirements of sustained release dosage form. The formulation F3 (polymer 1.75\%) showing the slowest drug release with $92 \%$ for 300 min. Comparisons of measure drug release of floating beads compared with conventional dosage form of amoxicillin showed different $(\mathrm{p}<0.05)$. The conventional dosage form of amoxicillin (Kimia Farma ${ }^{\circledR}$ ) showing the drug release with $97 \%$ for $30 \mathrm{~min}$. The percentage of amoxicillin release to all formulation floating beads and conventional dosage form shown in Fig. 7.

The correlation coefficient $\left(\mathrm{R}^{2}\right)$ to all formulas indicated release kinetics of floating beads followed Higuchi models (Fig. 8). Higuchi models describe low solubility drug release mechanism from matrix system in constant diffusion [20]. The data of kinetics model drug release shown in Table 5.

In the order, mechanism of drug release from floating beads was fitted to Korsmeyer-Peppas release model and interpretation of release exponent values (n). The $\mathrm{n}$ values $(\mathrm{F} 1=0.781 ; \mathrm{F} 2=0.665 ; \mathrm{F} 3=0.691$ ) of Korsmeyer-Peppas model (Table 5) indicated that the mechanism

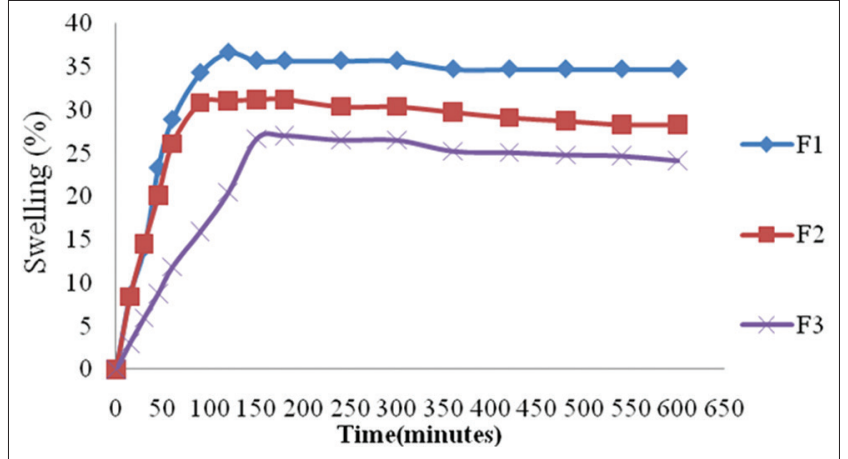

Fig. 6: Swelling properties of floating beads

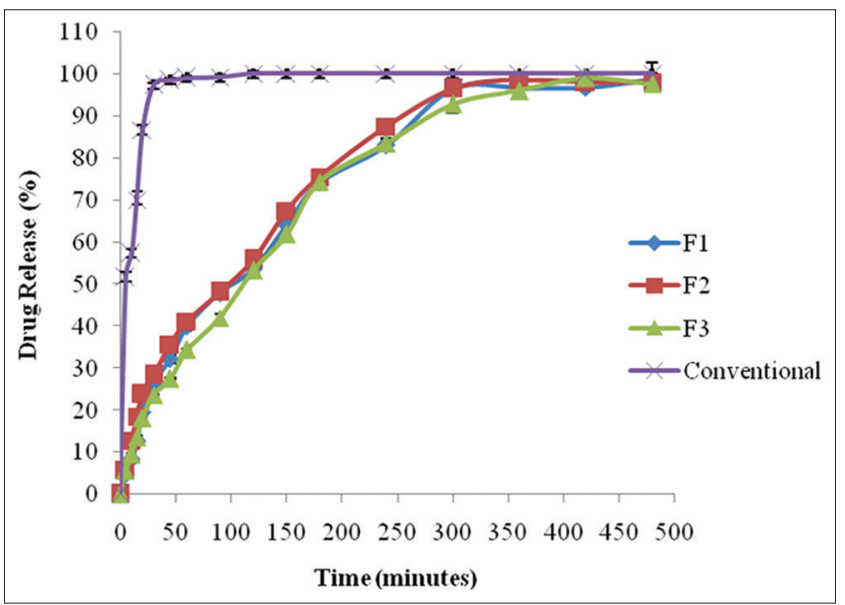

Fig. 7: Cumulative drug release

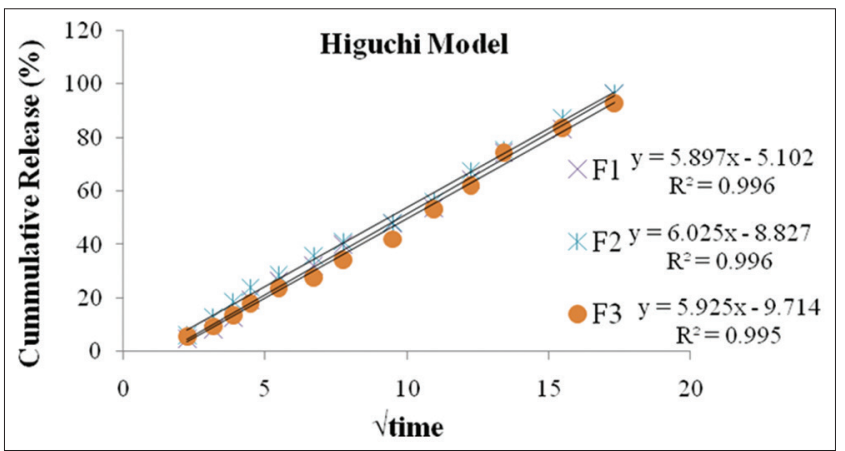

Fig. 8: Higuchi models kinetics drug release all batch

of drug release follows non-Fickian diffusion. This indicated, besides diffusion, mechanism of drug release from floating beads is swelling and erosion $[20,23]$.

\section{CONCLUSION}

1. Pectin was successfully isolated from banana peel using acid citric. The resulting low DE $(<50 \% \mathrm{DE})$ of acid citric isolated pectin indicated gelling properties of banana peel pectin requires the presence of calcium ions and compatible using as polymer in drug delivery system.

2. Gastroretentive floating beads amoxicillin using peel banana pectin as polymer is suitable for stomach targeted drug delivery in therapy peptic ulcer against $H$. pylori.

\section{ACKNOWLEDGMENTS}

Administrative Department of Pharmaceutical Sciences, Faculty of Pharmacy, Universitas Sumatera Utara, Medan, Indonesia. 


\section{AUTHOR CONTRIBUTIONS}

The first author has carried out the research. Second and third authors have provided study conception, the design of work, drafting of the manuscript and critical revision.

\section{CONFLICT OF INTEREST}

Declared none.

\section{REFERENCES}

1. Dipiro JT, Terry LS. Gastrointestinal disorders. In: Dipiro JT, Robert LT, Gary CY, Gary RM, Barbara GW, MichaelP, editors. Pharmavotherapy a Pathophysiologic Approach. $9^{\text {th }}$ ed. United States of America: McGraw; 2015. p. 251-5.

2. Cuña M, Alonso MJ, Torres D. Preparation and in vivo evaluation of mucoadhesive microparticles containing amoxicillin-resin complexes for drug delivery to the gastric mucosa. Eur J Pharm Biopharm 2001;51:199-205.

3. Hazell SL, Adrian L, Lynette B, William H. Campylobacter pyloridis and gastritis: Association with intercellular spaces and adaptation to an environment of mucus as important factors in colonization of the gastric epithelium. J Infect Dis 1986;153:658-64.

4. Nayak AK, Malakar J, Pal D. Development of cloxacillin loaded multiple-unit alginate based floating system by emulsion-gelation method. Int J Biol Macromol 2012;50:138-47.

5. Parkash V, Jogpal V, Maan S, Sharma V, Deepika, Yadav SK. Review on gastroretentive drug delivery system. Int J Pharm Life Sci 2011;2:773-81.

6. Katta S, Reddy MS, Rao NG. Overview on floating drug delivery system. Am J Pharmtech Res 2013;3:146-69.

7. Sadeghi M. Pectin-based biodegradable hydrogels with potential biomedical applications as drug delivery systems. J Biomater Nanobiotechnol 2011;2:36-40.

8. Morris GA, Samil MK, Stephen EH, Gary GA. Polysaccharide drug delivery systems based on pectin and chitosan. Biotechnol Gen Eng Rev 2010;27:257-84.

9. Sriamornsak P. Application of pectin in oral drug delivery. Expert Opin Drug Deliv 2011;8:1009-23.
10. Mishra RK, Banthia AK, Majeed AB. Pectin based formulation for biomedical applications: A review. Asian J Pharm Clin Res 2012;5:1-7.

11. Velmurugan S, Ali MA. Preparation and evaluation muchoadhesive microspheres gastroretentive drug delivery. Int J Pharm Pharm Sci 2015;7:208-14.

12. Ridley BL, Malcolm AO, Debra M. Pectins: Structure, biosynthesis, and oligogalacturonide -related signaling. Phytochemistry 2001;57:929-67.

13. Sato MF, Dayana CR, Maria HG, Carmen LO, Alessandro N, Gilvan W. Chemical and instrumental characterization of pectin from dried pomace of eleven apple cultivars. Acta Sci Agron Maringá 2011;33:383-9.

14. Sundari N. Extrication of pectin from waste peels: A Review. Res J Pharm Biol Chem 2015;6:1842-8.

15. Ujianto A. Peluang Pemanfaatan Limbah Pisang Sebagai Pakan Ternak. Prosiding Temu Teknis Fungsional non Peneliti. Badan Penelitian dan Pengembangan Pertanian; 2003. p. 53-7.

16. Anjum S, Sundaram S, Rai GK. Nutraceutical application and value addition of banana (Musa Paradisica L.) Variety "Bhuswal Keli" Peel: A Review. Int J Pharm Pharm Sci 2014;6:81-5.

17. Nazaruddin R, Noor Baiti AA, Foo SC, Tan YN, Ayob MK. Comparative chemical characteristics of hydrochloric acid and ammonium oxalateextracted pectin from roselle (Hibiscus sabdariffa L.) Calyces. Int Food Res J 2013;20:281-4

18. Kumar KV, Choudary PS, Ajaykumar B. Design and evaluation of stomach-specific drug delivery of domperidone using floating pectin beads. Int J Drug Dev Res 2013;5:219-28.

19. Jaiswal D, Bhattacharya A, Yadav IK, Singh HP, Chandra D, Jain DA. Formulation and evaluation of oil entrapped floating alginate beads of ranitidine hidrochloride. Int J Pharm Pharm Sci 2009;1:128-40.

20. Higuchi T. Mechanisms of sustained medications theoretical analysis of rate release of solid drugs dispersed in solid matrices. J Pharm Sci 1963;84:1464-77.

21. Shaikh HK, Kshirsagar RV, Patil SG. Mathematical models for drug release characterization: A review. World J Pharm Res 2015;4:324-38.

22. Dash S, Padala NM, Lilakanta N, Prasanta C. Kinetic modelling on drug release from controlled drug delivery system. Acta Poloniae Pharm Drug Res 2010;67:217-23.

23. Siepmann J, Peppas NA, Preface: Mathematical modeling of controlled drug delivery. Adv Drug Deliv Rev 2001;48:139-47.

24. Ramteke KH, Dighe PA, Kharat AR, Patil SV. Mathematical models of drug dissolution: A review. Sch Acad J Pharm 2014;3:388-96. 